ORIGINAL ARTICLE, MEDICINE

\title{
Association between Noise Pollution and Prevalent Ischemic Heart Disease
}

\author{
Angel M. Dzhambov' ${ }^{1}$ Donka D. Dimitrova² \\ ${ }^{1}$ Department of Hygiene and Ecological Medicine, Faculty of Public Health, Medical University of Plovdiv, Plovdiv, Bulgaria \\ ${ }^{2}$ Department of Health Management and Healthcare Economics, Faculty of Public Health, Medical University of Plovdiv, Plovdiv, \\ Bulgaria
}

\section{Correspondence:}

Angel M. Dzhambov, Department of Hygiene and Ecological Medicine, Faculty of Public Health, Medical University of Plovdiv, 15A Vassil Aprilov Blvd., 4002 Plovdiv, Bulgaria E-mail: angelleloti@gmail.com Tel: +35932580562

Received: 06 Sept 2015

Accepted: 08 July 2016

Published Online: 18 Oct 2016

Published: 23 Dec 2016

Key words: road traffic noise; occupational noise, ischemic heart disease, coronary heart disease; cardiovascular disease

Citation: Dzhambov AM, Dimitrova DD. Association between noise pollution and prevalent ischemic heart disease.

Folia Medica 2016;58(4):273-281

doi: 10.1515/folmed-2016-0041
Background: Noise pollution is considered a risk factor for ischemic heart disease (IHD). Both are highly prevalent in Bulgaria, but their association has not been studied sufficiently.

Aim: The aim of the present study was to examine the risk of IHD associated with road traffic ( $\left.L_{\text {den }}\right)$ and lifetime occupational noise exposure (LONE) in a Bulgarian sample.

Materials and methods: A cross-sectional survey was carried out among 513 residents of Plovdiv, Bulgaria. A questionnaire asked about doctor-diagnosed IHD, LONE and confounding factors. $L_{\text {den }}$ was derived from official noise map after geocoding participants' addresses. In log-link Poisson regressions we investigated the relative risks of prevalent IHD. Sensitivity analyses examined subgroup differences.

Results: $L_{\text {den }} \geq 65 \mathrm{~dB}$ was associated with higher risk ( $\left.R R=1.84,95 \% \mathrm{Cl}: 0.61,5.57\right)$ of IHD in long-term residents ( $\geq 20$ years). LONE was associated with $R R=1.76$ $(0.82,3.78)$ for ever-exposed; and $R R=2.35(1.00,5.52)$ for 15 - 47 years exposure.

Conclusions: Exposure to $L_{d e n} \geq 65 d B$ was associated with non-significantly higher risk of IHD. Longer LONE was consistently associated with higher risk. In some subgroups the effect of noise was more pronounced.

\section{BACKGROUND}

Ischemic heart disease (IHD) was responsible for 7.4 million deaths worldwide in $2012 .^{1}$ While individual and lifestyle determinants play an important role in its pathogenesis, environmental stressors such as noise pollution have been implicated as risk factors as well. Noise exerts its deleterious effects through direct and indirect neuroendocrine pathways, which ultimately lead to activation of the sympatheticadrenal system, disruption of sleep patterns, higher plasma cortisol and catecholamine release, and increased cardiovascular risk. ${ }^{2,3}$ A meta-analysis found a $1.08(95 \% \mathrm{CI}: 1.04,1.13)$ higher risk of coronary heart disease (CHD) per $10 \mathrm{~dB}$ increase of road traffic $\mathrm{L}_{\mathrm{DN}}{ }^{4}$ However, less is known about the association between occupational noise exposure and IHD. Heretofore, studies have been discordant due to differences in design and exposure/outcome definition. ${ }^{5}$ Gan et al. ${ }^{6}$ reported OR $=2.04(95 \% \mathrm{CI}$ : $1.16,3.58)$ among people exposed to loud noise for $1.6-18.8$ years, Virkkunen et al. ${ }^{7}$ found HR = $1.27(95 \% \mathrm{CI}: 1.13,1.44)$ for those exposed to $>80$ $\mathrm{dB}$ during an 18-year follow-up, while Jovanovic et al. ${ }^{8}$ did not find elevated odds for exposure to $>80 \mathrm{~dB}$, and neither did Thériault et al. ${ }^{9}$ Overall, although there was some evidence to suggest higher risk of IHD morbidity, it was limited. ${ }^{5}$

In Bulgaria, this topic is a pressing issue given that both IHD and noise exposure are highly prevalent. To put this in context, IHD was the cause for $12.7 \%$ of all deaths in $2012 .{ }^{10}$ The 2008 European Health Interview Survey showed that $8.3 \%$ of Bulgarians reported IHD. ${ }^{11}$ Conversely, $28 \%$ of all Bulgarians in urban areas are exposed to road traffic day-evening-night equivalent sound level $\left(\mathrm{L}_{\mathrm{den}}\right) \geq 65$ $\mathrm{dB}$ and the costs of road traffic noise-attributed 
myocardial infarction were estimated at about $€ 11.6$ million. ${ }^{12}$ According to the Sixth European Working Conditions Survey, in 2015, 28.8\% of the Bulgarian workers were exposed to noise so loud that they would have to raise their voice to talk to people during at least one fourth of the time. ${ }^{13}$ Nevertheless, few studies have explored the effects of noise on IHD. Tzenova et al. ${ }^{14}$ surveyed 1062 residents of Sofia and found significantly higher prevalence of IHD $(17.38 \%$ vs. $10.56 \%)$ in those exposed to residential $\mathrm{L}_{\text {eq } 6-22 \mathrm{~h}}>60 \mathrm{~dB}$ for 21 years, from which we could calculate $\mathrm{RR}=1.65$ (95\% CI:1.21,2.24).

Dimitrova and Karaslavova reported no effect of self-reported exposure to "excess production noise" on myocardial infarction among men $\left(\mathrm{OR}_{\text {unadjusted }}=0.680,95 \% \mathrm{CI}: 0.379,1.220\right)$, but significantly higher odds $\left(\mathrm{OR}_{\text {unadjusted }}=4.01,95 \%\right.$ CI:0.84,19.11) among women. ${ }^{15}$ Given this insufficient evidence, the aim of the present study was to examine the risk of IHD associated with road traffic and occupational noise exposure in a Bulgarian population.

\section{MATERIALS AND METHODS}

\section{Design AND VARIABLES}

This was a cross-sectional study carried out between July and November, 2014 in Plovdiv, Bulgaria. Participants were sampled via two procedures - a non-probability snowball method and field interviews (see ref. 16). Briefly, in the snowball sampling, the initial seeds were asked to recruit other members of their social network to ensure continuity of the procedure. In the field survey, the authors selected different neighborhood blocks representative of the geomorphological and land-use urban fabric of Plovdiv; the first author visited those sites and invited local residents to participate. Current residence in Plovdiv and age 18 years or older were the inclusion criteria; those reporting hearing loss or uncorrected hearing impairment were excluded.

Participants completed a questionnaire comprising questions about:

- demographics: age, gender, ethnicity, highest educational attainment, marital status, occupation, perceived socio-economic status

- self-reported doctor-diagnosis with IHD

- environmental exposures - lifetime occupational and residential noise exposure: "For how long during your lifetime have you worked at a place where noise was loud enough to disturb normal conversations?" and "For how long during your lifetime have you lived in a place where noise was loud enough to disturb normal conversations?"; after geocoding participants' addresses, we estimated the Euclidean distance to the nearest major road $(>10$ 000 vehicles/24h) based on satellite imagery (Google Earth $^{\mathrm{TM}}$ ) as a proxy for traffic-related air pollution; day-evening-night equivalent sound level $\left(\mathrm{L}_{\text {den }}\right)$ was extracted from official noise map of Plovdiv. ${ }^{16}$

- factors relevant to IHD (body-mass index, diagnosis with type 2 diabetes mellitus and arterial hypertension, pack-years of smoking)

- other potential confounders: noise sensitivity ${ }^{17}$, sleep disturbance ("0, very good" to " 10 , cannot sleep at all"), bedroom location (having a noisy façade or not) and duration of residence at the current address

\section{SAMPLE SIZE}

An a priori sample size was estimated using $\mathrm{G}^{*}$ Power v.3.1.9.2. For $\mathrm{L}_{\mathrm{den}} \geq 65 \mathrm{~dB}$ it was based on the risk estimate and the base rate of IHD in the non-exposed group reported by Tzenova et al. ${ }^{14}-817$ for $80 \%$ power and 482 for $60 \%$ power. For long-term LONE the calculations were based on the risk of CHD in long-term exposed workers reported by Gan et al. ${ }^{6}$ and the same base rate from Tzenova et al. ${ }^{14}-391$ for $80 \%$ power. A final sample of 513 residents was included in the analyses, after excluding those meeting exclusion criteria.

\section{Statistical analysis}

Variables were initially screened for patterns of missing data, univariate normality (D'Agostino-Pearson $\mathrm{K}^{2}$ test) and outliers (modified outlier labeling rule). The variable with highest percentage of missing values $(40.9 \%)$ was $L_{\text {den }}$ due to underreporting of residential addresses and it was not missing completely at random. Outliers were kept if they were considered true and honest answers. Ethnic minority members were combined into one group due to the lower number of Armenian, Roma, and Jewish participants, whereas the Turks were prevalent.

Descriptive statistics were computed. In case of non-normally distributed/categorical variables we used Spearman correlations and Pearson ChiSquare/Fisher's Exact Test/Fisher-Freeman-Halton Test. Welch's t-test and ANOVA were used even with non-normally distributed interval data due to their robustness to violations of normality and homogeneity of variance. ${ }^{18,19}$

The main analyses investigated the risk of prevalent IHD associated with lifetime occupational noise exposure (LONE) and $\mathrm{L}_{\mathrm{den}}$ exposure at the current address. We conducted log-link Poisson regressions 
to approximate the relative risk (RR). ${ }^{20,21} \mathrm{LONE}$ was included as categorical variable (ever vs. never exposed and different quartiles of exposure vs. never exposed); $\mathrm{L}_{\mathrm{den}}$ was dichotomized ( $\geq 65 \mathrm{~dB}$ vs. $<65 \mathrm{~dB}$ ), according to the threshold relevant to cardiovascular diseases (WHO, cited by Ref. 12). We specified several models with increasing adjustments: unadjusted model, basic model (age and gender-adjusted), main model, and fully adjusted model. The tool DAGitty v. 2.2 was used to construct directed acyclic graphs (DAGs) to determine a priori the sufficient adjustment sets for estimating the total effect of $\mathrm{L}_{\text {den }}$ and LONE in the main model without overadjusting (we forced pack-years of smoking and lifetime residential noise exposure in the main model for LONE, and pack-years of smoking, LONE, distance to major road, and duration of residence in the main model for $\left.\mathrm{L}_{\mathrm{den}}\right)$. The models were run on 50 imputed datasets. ${ }^{22}$ They were tested for multicollinearity. Finally, sensitivity analyses were conducted on the main model for LONE (per one interquartile range increase) and $\mathrm{L}_{\text {den }}$ ( $\geq 10$ years at the current address) to study possible effect modification by participants' characteristics.

Results were considered statistically significant at $\mathrm{p}<0.05$ (two-tailed). Data were processed with Statistical Package for the Social Sciences v. 17.0.

\section{RESULTS}

A total of 249 questionnaires were distributed via snowball sampling (85.5\% response rate); 1906 people were approached during the field sampling (19.3\% response rate). Data from 513 questionnaires were analyzed after additionally excluding 68 cases due to unacceptably high percentage of missing data on all key variables or due to meeting exclusion criteria.

Out of 513 participants, $35(6.82 \%)$ reported doctor-diagnosed IHD. According to Table 1, they were older, more often male, with lower educational level, widowed/divorced, retired, and with lower socio-economic status. They were more often diabetic and hypertensive, they had higher body mass index, had smoked more, were more sensitive to noise, reported more sleep disturbance, and had been exposed to occupational noise longer.

Overall, 163 participants $(31.77 \%)$ had been exposed to loud occupational noise at some point in their life. Median duration of exposure among those participants was 7 years (IQR $=14$ years) and it was positively associated with age $\left(\mathrm{r}_{\mathrm{s}}=0.79\right.$, 95\% CI: $0.72,0.84)$, body mass index $\left(r_{s}=0.33\right.$,
95\% CI: $0.18,0.46)$, pack years of smoking $\left(\mathrm{r}_{\mathrm{s}}=\right.$ $0.20,95 \%$ CI: $0.05,0.35)$, and sleep disturbance $\left(r_{s}\right.$ $=0.19,95 \% \mathrm{CI}: 0.04,0.34)$. It was longer in men and pensioners (data not shown). $\mathrm{L}_{\text {den }}$ levels in the dataset ranged from 50 to $80 \mathrm{~dB}$. One hundred and ninety-seven $(38.40 \%)$ participants were exposed to $\mathrm{L}_{\mathrm{den}} \geq 65 \mathrm{~dB}$ and it was associated with higher body mass index (23.55, $\mathrm{SD}=4.60$ vs. $22.29, \mathrm{SD}=3.67)$, marital status, and occupation (data not shown).

Table 2 shows associations between IHD and $\mathrm{L}_{\text {den }}$ for people with different duration of residence. No significantly elevated risk was observed across the models regardless of duration of residence and adjustment sets. Regarding LONE, ever-exposed people had $\mathrm{RR}=1.76$ increased risk; those exposed for 15-47 years had $R R=2.35$ increased risk, with evidence of linear trend across the quartiles of exposure (Table 3).

After stratification by participants' characteristics, there was marginally significantly increased risk associated with $\mathrm{L}_{\text {den }}$ among people with lower socioeconomic status, whereas in those with middle and upper socioeconomic status there was no risk. In ethnic minorities the risk reached $\mathrm{RR}=4.2$ (95\% CI: $1.14,15.48)$. The other interaction terms were non-significant at $\mathrm{p}<0.25$ (Fig. 1). The risk associated with LONE was significantly higher among ethnic minority members in comparison to Bulgarians (Fig. 2). The risk estimates themselves were significant among women, ethnic minorities, smokers, and participants without diabetes.

\section{DISCUSSION}

Overall, this study suggested non-significantly increased risk of prevalent IHD in association with $\mathrm{L}_{\text {den }}$. Some foreign studies reviewed by Babisch also reported null results. ${ }^{4}$ The exposure threshold of 60 $\mathrm{dB} \mathrm{L}_{\text {eq } 6-22 \mathrm{~h}}$ previously used by Tzenova et al. ${ }^{14}$ can be converted to approximately $62 \mathrm{~dB} \mathrm{~L}_{\mathrm{den}}{ }^{23}$ which is somewhat comparable to the $65-\mathrm{dB}$ threshold used in our study. We corroborated the high risk among those exposed to these levels for over 20 years, although our estimate failed statistical significance.

LONE, conversely, was associated with significantly increased risk among long-term employees and other subgroups.

With respect to occupational noise, among ethnic minorities there was evidence of more pronounced risk of IHD for every 13 years of employment, but the results were inconclusive due to the wide confidence interval of the risk estimate. In similar vein as Dimitrova and Karaslavova ${ }^{15}$, we found higher 
Table 1. Sample characteristics according to participants' ischemic heart disease (IHD) status

\begin{tabular}{|c|c|c|c|}
\hline Participants' characteristics $^{\mathrm{a}}$ & No IHD & IHD & p-value ${ }^{b}$ \\
\hline Age, mean (SD) & $34.71(14.25)$ & $59.45(11.47)$ & $<0.001$ \\
\hline Gender: men, n (\%) & $159(33.67)$ & $24(68.57)$ & $<0.001$ \\
\hline Ethnicity: Bulgarians, n (\%) & $407(86.41)$ & $26(74.29)$ & 0.075 \\
\hline Educational attainment & & & 0.002 \\
\hline basic & $3(0.64)$ & $4(11.43)$ & \\
\hline upper secondary & $238(50.42)$ & $17(48.57)$ & \\
\hline master/bachelor & $218(46.19)$ & $14(40)$ & \\
\hline $\mathrm{PhD} / \mathrm{DSc}$ & $13(20.75)$ & $0(0.00)$ & \\
\hline Marital status & & & 0.018 \\
\hline married/spouse & $290(61.57)$ & $25(71.43)$ & \\
\hline single & $151(32.06)$ & $5(14.29)$ & \\
\hline widowed & $9(1.91)$ & $3(8.57)$ & \\
\hline divorced & $21(4.46)$ & $2(5.71)$ & \\
\hline Occupation & & & $<0.001$ \\
\hline employed & $261(55.41)$ & $21(60.00)$ & \\
\hline studying & $172(36.52)$ & $0(0.00)$ & \\
\hline unemployed & $17(3.60)$ & $1(2.86)$ & \\
\hline retired & $21(4.46)$ & $13(37.14)$ & \\
\hline Socio-economic status & & & 0.024 \\
\hline lower & $120(25.53)$ & $16(45.71)$ & \\
\hline middle & $331(70.43)$ & $17(48.57)$ & \\
\hline upper & $19(4.04)$ & $2(5.71)$ & \\
\hline Body mass index, mean $(\mathrm{SD})\left(\mathrm{m}^{2} / \mathrm{kg}\right)$ & $22.99(4.06)$ & $27.47(5.44)$ & $<0.001$ \\
\hline Type 2 diabetes mellitus: yes, $\mathrm{n}(\%)$ & $21(4.46)$ & $14(42.42)$ & $<0.001$ \\
\hline Arterial hypertension: yes, $\mathrm{n}(\%)$ & $71(15.04)$ & $30(88.24)$ & $<0.001$ \\
\hline Pack-years of smoking, mean (SD) & $4.37(8.66)$ & $23.75(30.34)$ & 0.001 \\
\hline Residential noise exposure (years), mean (SD) & $2.51(6.73)$ & $6.49(12.32)$ & 0.067 \\
\hline $\mathrm{L}_{\mathrm{den}} \geq 65 \mathrm{~dB}, \mathrm{n}(\%)$ & $184(64.79)$ & $8(53.33)$ & 0.412 \\
\hline Distance to major road (meters), mean (SD) & $121.62(113.08)$ & $151.93(92.60)$ & 0.240 \\
\hline Occupational noise exposure (years), mean (SD) & $2.56(6.53)$ & $14.74(13.97)$ & $<0.001$ \\
\hline Noise sensitivity, mean (SD) & $3.33(0.77)$ & $3.59(0.59)$ & 0.024 \\
\hline Sleep disturbance, mean (SD) & $3.97(3.11)$ & $5.82(1.75)$ & $<0.001$ \\
\hline Bedroom façade: noisy, n (\%) & $122(27.42)$ & $9(29.03)$ & 0.837 \\
\hline
\end{tabular}

Note: ${ }^{\mathrm{a} P e r c e n t a g e s}$ are reported within the IHD status; ${ }^{\mathrm{b}} \mathrm{p}$-value for Welch's t-test or Pearson Chi-Square/Fisher's Exact Test/Fisher-Freeman-Halton Test. $\mathrm{L}_{\mathrm{den}}$ - day-evening-night equivalent sound level.

risk among women exposed to noise at work. Gan et al. ${ }^{6}$ conducted a cross-sectional survey using selfrated noise exposure and found more pronounced odds of CHD among men and long-term exposed participants.

The ethnic differences that we found might be quite important and need to be studied in future research. The fact that noise exposure and IHD did not differ considerably between Bulgarians and ethnic minority members suggests a more complex explanation - in addition to environmental health disparities, the access to health services, lifestyle, religious, nutritional, and genetic factors might play a modifying role. Some minorities in Plovdiv like the Roma live in neighborhoods where leisure time noise from different cultural and religious practices (e.g., loud music at weddings on the outside) is a serious environmental nuisance, which could amplify the effects of occupational noise. It is also possible that ethnic minority members get 
Table 2. Associations between ischemic heart disease (IHD) and exposure to $\mathrm{L}_{\mathrm{den}} \geq 65 \mathrm{~dB}$ among people with different duration of residence at the current address (log-link Poisson regression models)

\begin{tabular}{lcccc}
\hline & \multicolumn{4}{c}{ RR (95\% CI) according to duration of residence } \\
\cline { 2 - 5 } & All participants & $\geq \mathbf{5}$ years & $\geq \mathbf{1 0}$ years & $\geq \mathbf{2 0}$ years \\
\cline { 2 - 5 } $\begin{array}{l}\text { No. of cases with IHD } \\
\text { Model (sample size) }\end{array}$ & 37 & 36 & 32 & 26 \\
Unadjusted & & & & \\
$(513 / 370 / 300 / 190)$ & $0.91(0.34,2.40)$ & $0.74(0.29,1.91)$ & $0.77(0.31,1.91)$ & $0.76(0.29,2.01)$ \\
Basic $^{\mathrm{a}}(513 / 370 / 300 / 190)$ & $1.38(0.55,3.43)$ & $1.31(0.52,3.29)$ & $1.48(0.61,3.56)$ & $1.46(0.58,3.66)$ \\
Main $^{\mathrm{b}}(513 / 370 / 300 / 190)$ & $1.49(0.55,4.03)$ & $1.37(0.51,3.67)$ & $1.57(0.59,4.18)$ & $1.84(0.61,5.57)$ \\
Fully adjusted $_{(513 / 370 / 300 / 187)}$ & $1.01(0.37,2.71)$ & $0.94(0.34,2.56)$ & $1.04(0.41,2.65)$ & $1.62(0.50,5.19)$ \\
\hline
\end{tabular}

Note: Models are based on 50 imputed datasets. ${ }^{\mathrm{a}}$ Model is adjusted for age and gender; ${ }^{\mathrm{b}}$ Additionally adjusted for ethnicity, socio-economic status, educational attainment, pack-years of smoking, lifetime occupational noise exposure, distance to major road and duration of residency; ${ }^{\mathrm{c}}$ Additionally adjusted for body mass index, type 2 diabetes mellitus, arterial hypertension, noise sensitivity, sleep disturbance and bedroom location; $\mathrm{L}_{\mathrm{den}}$ - day-evening-night equivalent sound level.

Table 3. Associations between ischemic heart disease (IHD) and quartiles of lifetime occupational noise exposure (log-link Poisson regression models)

\begin{tabular}{|c|c|c|c|c|c|c|}
\hline & \multirow{2}{*}{$\begin{array}{c}\text { RR }(95 \% \text { CI }) \\
\text { among ever } \\
\text { exposed }^{\mathrm{a}} \\
\end{array}$} & \multicolumn{4}{|c|}{ RR $\left(95 \%\right.$ CI) according to the quartiles of exposure ${ }^{a}$} & \multirow[t]{2}{*}{ Trend $^{\mathrm{e}}$} \\
\hline & & $\begin{array}{c}0.02-1 \\
\text { years }\end{array}$ & $\begin{array}{l}1-7 \\
\text { years }\end{array}$ & $\begin{array}{l}7-15 \\
\text { years }\end{array}$ & $\begin{array}{c}15-47 \\
\text { years }\end{array}$ & \\
\hline No. of cases with IHD & 23 & 0 & 2 & 6 & 16 & \\
\hline \multicolumn{7}{|l|}{ Model (sample size) } \\
\hline Unadjusted (510) & $3.55(1.78,7.05)^{*}$ & $<0.01$ & $0.91(0.21,4.02)$ & $3.48(1.31,9.25)^{*}$ & $9.79(4.89,19.62)^{*}$ & 0.001 \\
\hline Basic $^{b}(510)$ & $2.08(1.05,4.11)^{*}$ & $<0.01$ & $1.29(0.31,5.29)$ & $1.52(0.53,4.36)$ & $3.04(1.45,6.37)^{*}$ & 0.025 \\
\hline Main $^{\mathrm{c}}(500)$ & $1.76(0.82,3.78)$ & $<0.01$ & $1.33(0.37,4.82)$ & $1.39(0.40,4.76)$ & $2.35(1.00,5.52)$ & 0.069 \\
\hline Fully adjusted $^{\mathrm{d}}(500)$ & $1.29(0.67,2.49)$ & $<0.01$ & $1.18(0.44,3.18)$ & $1.60(0.52,4.94)$ & $1.24(0.58,2.66)$ & 0.444 \\
\hline
\end{tabular}

Note: Models are based on 50 imputed datasets. ${ }^{a}$ Reference category: never exposed (14 cases with IHD). ${ }^{b}$ Model is adjusted for age and gender; ${ }^{\mathrm{c}}$ Additionally adjusted for ethnicity, socio-economic status, educational attainment, packyears of smoking and lifetime residential noise exposure; ${ }^{\mathrm{d}}$ Additionally adjusted for distance to major road, body mass index, type 2 diabetes mellitus, arterial hypertension, noise sensitivity, sleep disturbance, bedroom location and duration of residence; ${ }^{\mathrm{e}} \mathrm{p}$-value for linear trend across the means of the exposure categories; *statistically significant at $\mathrm{p}<0.05$.

employed as blue-collar workers more often due to prejudice or bigotry; we did not have job title description, which would have allowed us to determine the noise source in participants' occupational environment, but the exposure to machine noise, prevalent among blue-collar workers, might differ in its effects on IHD from "social noise" due to differences in frequency spectrum or impulse-noise characteristics, despite the fact that both may elicit the same vocal effort to talk to others; blue-collar workers are also co-exposed to vibrations, extreme temperatures, chemicals, physical strain, etc. Thus, un-modeled residual confounding cannot be ruled out. This merits further research given the ethnic structure of our society and the unfavorable milieu and physical environment of some minorities.

\section{STRENGTHS AND LIMITATIONS}

This study was one of the few to specifically focus on the effects of both occupational and road traffic noise on IHD in Bulgaria. It used objective measure of road traffic noise and adjusted for most of the 


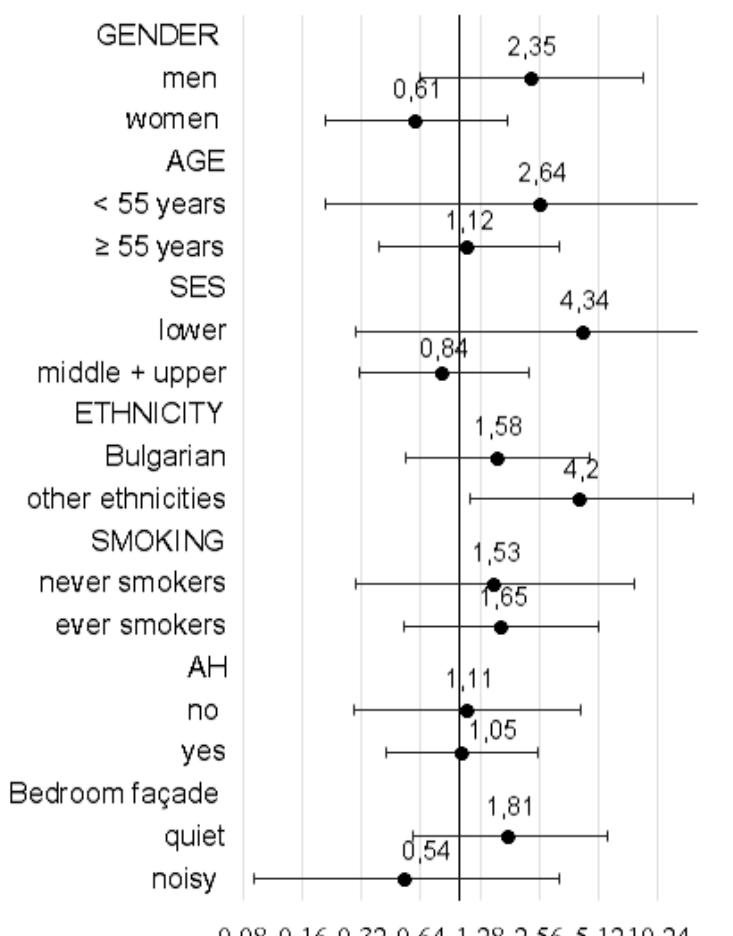

Relative risk $(95 \% \mathrm{Cl})$

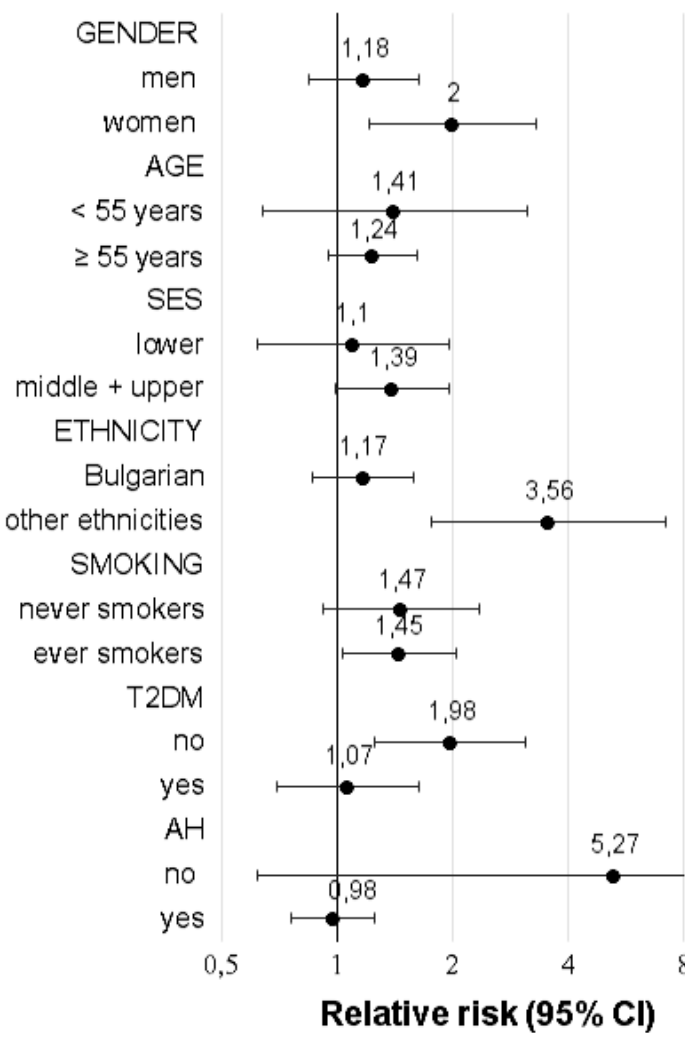

Note: Models are based of 50 imputed datasets. Models are adjusted for age, gender, ethnicity, socio-economic status, education, pack-years of smoking and lifetime residential noise exposure (unless the results are stratified by the respective covariate); SES - socio-economic status, T2DM - type 2 diabetes mellitus, $\mathrm{AH}$ - arterial hypertension. (unless the results are stratified by the respective covariate); SES - socio-economic status, AH - arterial hypertension, $\mathrm{L}_{\text {den }}$ - day-evening-night equivalent sound level.

Figure 1. Association between ischemic heart disease and exposure to road traffic $\mathrm{L}_{\mathrm{den}} \geq 65 \mathrm{~dB}$ among longterm residents ( $\geq 10$ preceding years) stratified by participants' characteristics (log-link Poisson regression models).

relevant covariates. ${ }^{4,5}$

Like some previous studies ${ }^{6,14}$ ours has limitations. Its cross-sectional design means that we could not confirm that the exposure preceded the outcome. However, it met important criteria for causation (consistency, biological plausibility, coherence) which makes it acceptable. ${ }^{24}$ The smallish sample size might explain some non-significant estimates; Babisch, on the other hand, advocated for interpretation of confidence intervals rather than $p$-values ${ }^{25}$, which are, according to some, misleading in epidemiological research ${ }^{26}$. However, because of the low number of different ethnic minority members, they were all analyzed under one group.

Some of the covariates (e.g., sleep disturbance,
Figure 2. Association between ischemic heart disease and one interquartile range increase in lifetime occupational noise exposure stratified by participants' characteristics (log-link Poisson regression models).

noise sensitivity) were relevant only for the past year and therefore, temporally unstable. The low response rate and mixed sampling inhibits generalization of the findings, but this was not our objective and, given the sufficient breadth of the data, it should not be concerning.

Self-reported IHD might underestimate the true prevalence of the disease. However, in a populationbased male survey self-reported doctor-diagnosis with angina pectoris was found to be a valid measure. ${ }^{27}$ Another study of 34616 employees found $78 \%$ sensitivity and $99 \%$ specificity of self-reported coronary heart disease. ${ }^{28}$

Self-rated LONE is another possible source of bias, as we had no data on whether participants' oc- 
cupational exposure exceeded the hygiene standards, which would be important because the mechanism of action across the loudness spectrum and the respective health effects of noise vary. On the other hand, speakers' vocal effort in a noisy occupational environment is often used to identify exposed individuals in epidemiological studies. Depending on the question, different noise intensities can be approximated. ${ }^{29}$ For example, when people are 4 feet apart speaking in raised voice to hold a conversation is a proxy for $87 \mathrm{~dB}^{30}$, whereas ISO $9921 / 1: 1996$ and Lazarus suggest that for speakers at a distance of 1 meter the need to raise their voice represents a threshold of $66 \mathrm{~dB}^{31}$. Unfortunately, we had no information on hearing protection during work, noise sources, frequencies, whether it was continuous or intermittent, or other occupational factors such as microclimate, stress, vibrations, and physical strain. Overall, both self-reports (IHD and LONE) bias the results towards the null, making them conservative.

\section{FURTHER RESEARCH}

Despite the limitations of this study, it provides much needed basis for further research in the country. In the recent years, the attention of public health experts has shifted away from noise hygiene, which stands in contrast to the current trend in Europe; moreover, there is a high demand for evidence from middle-to-low income countries such as Bulgaria. If relevant questions are included in the routine population-based surveys (by the National Center of Public Health and Analyses or the National Statistical Institute) or in surveys on working conditions, the research on the cardiovascular effects of noise will be advanced at relatively low cost. Moreover, there is a high demand for a contemporary job-exposure matrix representative of the noise levels across all job titles in Bulgaria, which would facilitate objective exposure assessment.

\section{CONCLUSIONS}

There was non-significantly increased risk of prevalent IHD associated with exposure to $\mathrm{L}_{\mathrm{den}} \geq 65 \mathrm{~dB}$. LONE was associated with statistically significantly increased risk. There was some evidence that among ethnic minority members the risk was more pronounced, but it was not conclusive.

\section{ACKNOWLEDGEMENTS}

The authors would like to thank all contributors who recruited other participants during the snowball sampling and all participants who made this study possible. This study received no external funding.

\section{CONFLICT OF INTEREST STATEMENT}

The authors declare that, with respect to this study, they do not have any potential conflict of interest.

\section{REFERENCES}

1. WHO Fact sheet: Cardiovascular diseases (CVDs); 2015.

2. Spreng M. Central nervous system activation by noise. Noise Health 2000;2:49-58.

3. Babisch W. The noise/stress concept, risk assessment and research needs. Noise Health 2002;4(16):1-11.

4. Babisch W. Updated exposure-response relationship between road traffic noise and coronary heart diseases: A meta-analysis. Noise Health 2014;16:1-9.

5. Dzhambov AM, Dimitrova DD. Occupational noise and ischemic heart disease: A systematic review . Noise Health 2016;18:167-77.

6. Gan WQ, Davies HW, Demers PA. Exposure to occupational noise and cardiovascular disease in the United States: the National Health and Nutrition Examination Survey 1999-2004. Occup Environ Med 2011;68:183-90.

7. Virkkunen H, Kauppinen T, Tenkanen L. Long-term effect of occupational noise on the risk of coronary heart disease. Scand J Work Environ Health 2005;31:291-9.

8. Jovanovic J, Popovic V, Milosevic Z, et al. Cumulative effects of communal and industrial noise on cardiovascular system. Sci J Facta Univ 1997;4:57-61.

9. Thériault GP, Tremblay CG, Armstrong BG. Risk of ischemic heart disease among primary aluminum production workers. Am J Ind Med 1988;13:659-66.

10. Ministry of Health - National Statistical Institute. [Healthcare 2013] (in Bulgarian).

11. National Statistical Institute. European Health Interview Survey (Main results); 2008 (in Bulgarian).

12. Dzhambov AM, Dimitrova DD. Evaluation of the social and economic burden of road traffic noise-attributed myocardial infarction in Bulgarian urban population. Arh Hig Rada Toksikol 2015;66(1):15-21.

13. Eurofound. Sixth European Working Conditions Survey; 2015.

14. Tzenova B, Radneva R, Tzvetkov D, et al. [Characteristics of noise exposure in modern living environment and their health effects]. Hyg Public Health 2000;5-6:29-33 (in Bulgarian) 
15. Dimitrova T, Karaslavova E. [Vibrations in the working environment and risk of acute myocardial infarction]. Med Rev 2008;44:54-7 (in Bulgarian).

16. Dzhambov A, Dimitrova D. Road traffic noise and annoyance: exposure-response relationship and burden of disease calculations in Bulgaria. Scr Sci Med 2015;47(2):22-30.

17. Dzhambov AM, Dimitrova DD. Validating a short Bulgarian version of a psychometric instrument for multidimensional noise sensitivity assessment. Folia Med 2014;56:116-25.

18. Schmider E, Ziegler M, Danay E, et al. Is it really robust? Reinvestigating the robustness of ANOVA against violations of the normal distribution assumption. Meth Eur J Res Meth Behav Soc Sci 2010;6(4):147-51.

19. Tomarken AJ, Serlin RC. Comparison of ANOVA alternatives under variance heterogeneity and specific noncentrality structures. Psychol Bull 1986;99(1):90-9.

20. Duijnhoven RG, Knol MJ. Logistic regression and odds ratios as means to adjust for baseline incomparability's in randomised controlled trials: description of the disadvantages, alternatives and frequency of use. University of Utrecht, Utrecht; 2012.

21. McNutt LA, Wu C, Xue X, et al. Estimating the relative risk in cohort studies and clinical trials of common outcomes. Am J Epidemiol 2003; 157:940-3.

22. He Y. Missing data analysis using multiple imputation: getting to the heart of the matter. Circ Cardio- vasc Qual Outcomes 2010;3:98-105.

23. EEA Expert Panel of Noise (EPoN). Good practice guide on noise exposure and potential health effects. EEA Technical report No 11/2010. Copenhagen: European Environment Agency; 2010.

24. Niemann H, Bonnefoy X, Braubach M, et al. Noise-induced annoyance and morbidity results from the pan-European LARES study. Noise Health 2006;8:63-79.

25. Babisch W. Transportation noise and cardiovascular risk, review and synthesis of epidemiological studies, dose effect curve and risk estimation, WaBoLuHefte, 01/06. Berlin, Umweltbundesamt, 2006.

26. Poole C. Low P-values or narrow confidence intervals: which are more durable? Epidemiology 2001;12(3):291-4.

27. Lampe FC, Walker M, Lennon LT, et al. Validity of a self-reported history of doctor-diagnosed angina. J Clin Epidemiol 1999;52(1):73-81.

28. Oksanen T, Kivimäki M, Pentti J, et al. Self-report as an indicator of incident disease. Ann Epidemiol 2010;20(7):547-54.

29. Guideline for diagnosing occupational noise-induced hearing loss. Part 1: McBride D. Noise effects and duration. Report for ACC, November 2010.

30. Smith PA, Davis A, Ferguson M, et al. The prevalence and type of social noise exposure in young adults in England. Noise Health 2000;6(2):41-56.

31. Lazarus H. Prediction of verbal communication is noise - a review: Part 1. App Acoust 1986;19:439-64. 


\title{
Связь между шумовым загрязнением и распространением ишеми- ческой болезни сердца
}

\author{
Ангел М. Джамбов ${ }^{1}$, Донка Д. Димитрова ${ }^{2}$ \\ ${ }^{1}$ Кафедра гигиены и экологической медицины, Факультет общественного здоровья, Медицинский университет, Пловдив, \\ Болгария \\ ${ }^{2}$ Менеджмент здоровья, Экономика здравоохранения и общая медицина, Факультет общественного здоровья, Медицин- \\ ский университет, Пловдив, Болгария
}

\section{Адрес корреспонденции: Ангел М. Джамбов, Кафедра гигиены и экологической медицины, Факультет общественного здоровья, Медицинский университет - Пловдив, бул. Васила Априлова № 15A, 4002 Пловдив, Болгария \\ E-mail: angelleloti@gmail.com Тел.: +35932580562}

Дата получения: 06 сентября 2015 г.

Дата приемки: 08 июля 2016 г. Дата онлайн публикации: 18 октября 2016 г.

Дата публикации: 23 декабря 2016 г.

\section{Ключевые слова: шум от} дорожного движения, шум на рабочем месте, ишемическая болезнь сердца, коронарная болезнь сердца, сердечнососудистые заболевания

Образец цитирования: Dzhambov AM, Dimitrova D. Association between noise pollution and prevalent ischemic heart disease.

Folia Medica 2016;58(4):273-281 doi: 10.1515/folmed-2016-0041
Контекст: Шумовое загрязнение считается фактором, обуславливающим риск появления ишемической болезни сердца (ИБС). Оба явления имеют широкое распространение в Болгарии, однако связь между ними все еще не исследована в достаточной степени.

Цель: Целью данного исследования является анализ риска возникновения ИБС, связанного с дорожным движением $\left(\mathrm{L}_{\mathrm{den}}\right)$ и нахождением в шумных условиях на рабочем месте в течение всей жизни (LONE), в болгарской выборке.

Материалы и методы: Перекрестное исследование было проведено в числе 513 жителей города Пловдива в Болгарии. В анкету были включены вопросы относительно наличия диагностицированной врачом ИБС, LONE и раздражающих факторов. Результаты относительно $L_{\text {den }}$ получены с помощью официальной карты шума после геокодирования адресов участников. С помощью линейной регрессии Пуассона нами были исследованы относительные риски распространения ИБС. С помощью анализа чувствительности были исследованы субгруппы с различиями.

Результаты: $L_{\text {den }} \geq 65$ dB связан с более высоким риском (RR=1.84, 95\% Cl: 0.61, 5.57) возникновения ИБС в случае долгосрочного воздействия фактора ( $\geq 20$ лет). LONE связан с RR=1.76 $(0.82,3.78)$ в случае постоянного воздействия фактора; $R R=2.35$ (1.00, 5.52) - в случае воздействия фактора в течение 15 - 47 лет.

Заключение: Воздействие фактора $L_{d e n} \geq 65 \mathrm{~dB}$ связано с более высоким риском возникновения ИБС. Более продолжительное воздействие фактора LONE последовательно связано с более высоким риском. В некоторых субгруппах эффект шума выражен сильнее. 